\title{
RESEARCH OFFERED NEW POSSIBILITIES FOR NUT GROWING IN THE NETHERLANDS
}

C. J. GERRITSEN

Institute of Horticultural Plant Breeding, Wageningen, Netherlands Received 28 Jan. 1956

\section{INTRODUCTION}

The walnut, Juglans regia, is not indigenous to the Netherlands; it was probably

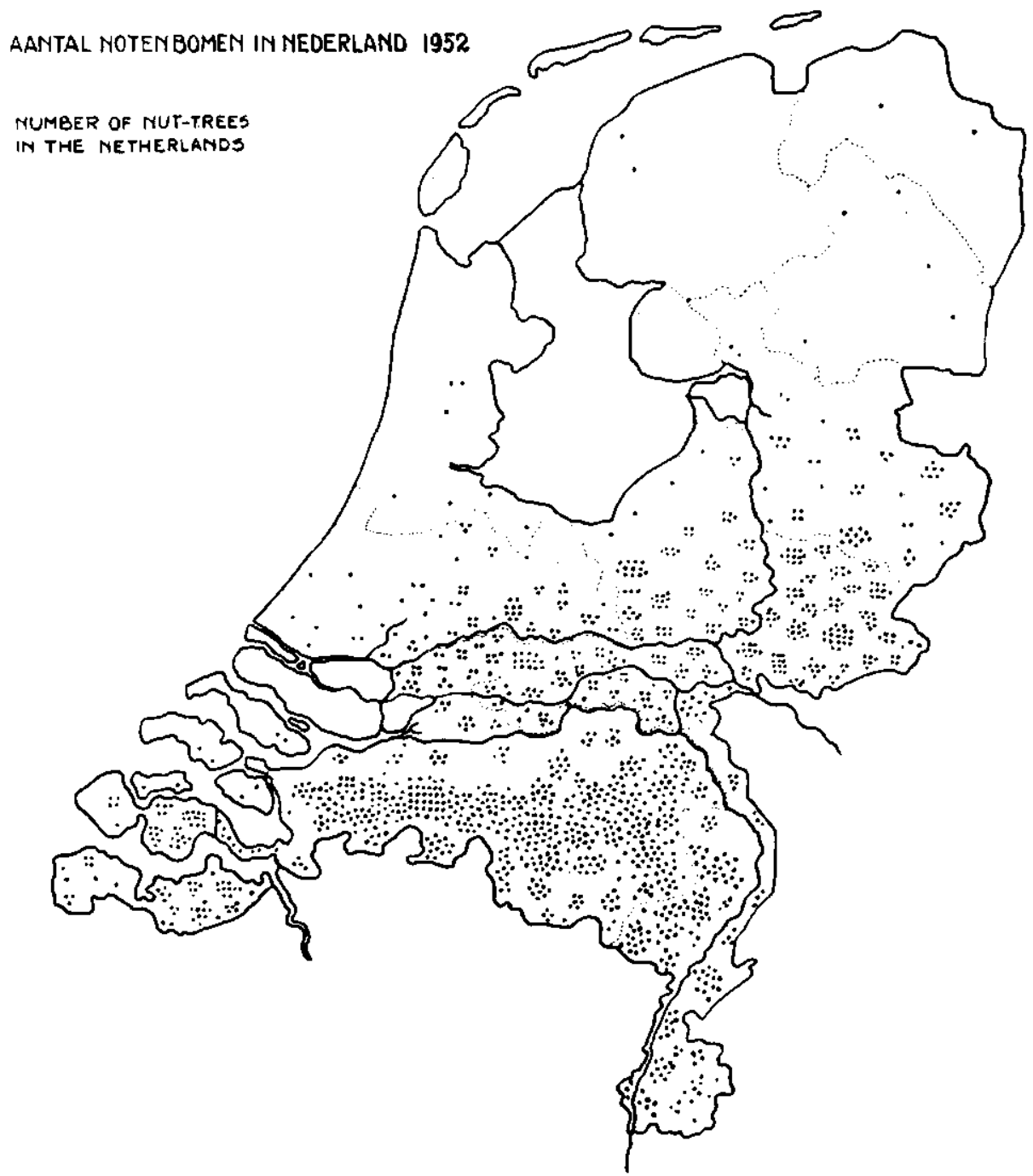

Fig. 1. The OCCURRence of Nut trees IN THE NETHERLANds (Data from the C.B.S., $\bullet=25$ trees) 


\section{J. GERRITSEN}

introduced into this country by the Romans. Later Charlemagne did much to spread it. In the Middle Ages many nuts were already commercialized. The situation did not alter much until the beginning of this century, when nut-trees were still large in number in our country; unfortunately reliable records of this number are not available but a rough estimate is some hundreds of thousands.

The number of trees has much decreased since then. Recently, however, as a result of research work and the search for better varieties, more interest has been taken in nut growing.

\section{CAUSES OF THE DECREASE IN NUMBER OF NUT-TREES}

Among the causes of this decrease we may mention:

1. an economic one: increasing lack of soil compels the growing of crops which, by breeding and improvement, become more profitable, whereas no work has been done on the seedling nut, which occupies too much space and is often low in productivity and fruit quality, or both;

2. a military cause: in the first world war all nut-trees with good trunks had to be felled for the manufacture of rifle-butts;

3. a psychological cause : in general seedling nuts are very slow to come into bearing; at present growers no longer have enough patience - apart from the economic motive - to wait very long;

4. a matter of waterway engineering: formerly many trees were grown along the river-dikes; this is no longer allowed.

As a result the number of nut-trees had decreased to a low level before the second world war; the trees which were still found were all seedlings and not properly cared for.

During and immediately after the second world war the interest in the walnut became greater, probably due to its high calorific value and high prices. But as soon as normal food supply had been restored the interest in the nut rapidly decreased. If nothing else had happened, no doubt the number of trees would have gradually decreased to an odd tree here and there on farmgrounds, or with amateurs (who grow. them for the fresh fruit). But something did happen: it was made the object of some research.

\section{RESEARCH HAS STARTED}

First, it was ascertained whether such research would be a paying proposition, in other words, if it would be possible to grow nuts profitably under Dutch conditions, with varieties that could face the competition of imported nuts, and of other crops in view of the relative scarcity of available land. When this appeared probable, research into good varieties as well as research on propagation was started.

\section{Propagation OF NUT TREeS}

Grafting or budding nuts in the open is practically impossible. Hence formerly the culture did not make any progress. One always had to sow again even if good varieties were available, and the nut does not breed true from seed. Much research has been carried out to find a satisfactory grafting method, but it was shown again and again, that 
RESEARCH OFFERED NEW POSSIBILITIES FOR NUT GROWING

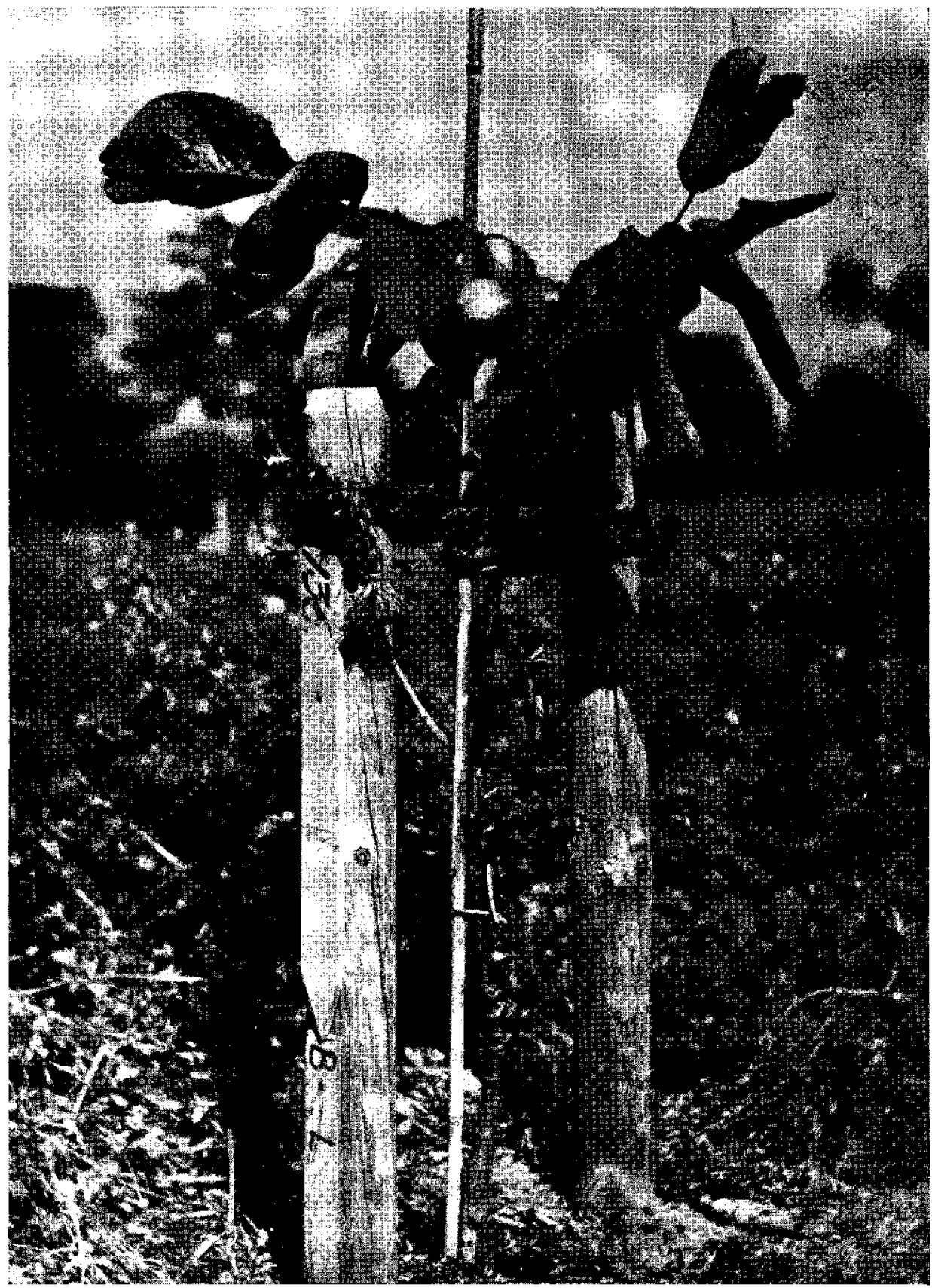

Fig. 2. Production In the 2ND year aFter GRAFting; 


\section{J. GERRITSEN}

in our climate it is not possible to graft out of doors. A method of use to nurserymen has been developed by Mr. FLOOR, of our Institute. The method is now being applied by the Dutch nurseries. In the present paper I will not go into it in detail, but will restrict myself to saying that grafting is carried out in a closed case, under a certain constant humidity and at a certain constant temperature. The quality of scionwood and stocks, and controlled conditions proved to be more important than the method used.

\section{SEARCH FOR BETTER VARIETIES}

Good varieties were, and are, collected in 2 different ways: on the one hand the most important foreign varieties are imported and tested; on the other selections are carried out among Dutch seedling material.

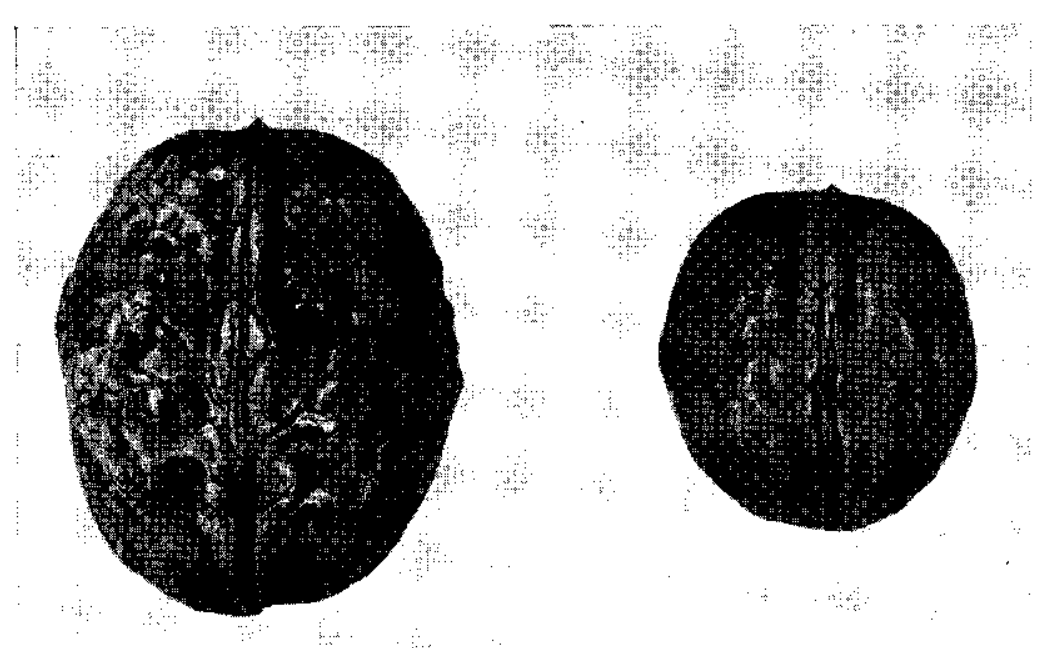

Fig. 3. THE CONTENTS IS MORE IMPORTANT THAN THE SIZE (AT LEAST FOR THE CONSUMER); BOTH NUTS HAVE AN EQUALLY HEAVY KERNEL (3.1 G), WHILE THE LARGEST WEIGHS $14 \mathrm{G}$ AND THE OTHER ONE ONLY $6.5 \mathrm{G}$

For the time being only such foreign varieties are imported as are grown in climates which do not differ greatly from ours; in addition, of these varieties as many fruits as possible are examined in order to see whether they meet our requirements.

The search for good Dutch seedlings is made in different ways. For instance a prize was offered for the best nut, and appeals are regularly made in the agricultural journals for sending in good nuts (for which prizes are offered as well). Furthermore the officers of the Advisory Service, and of the Netherlands General Inspection Service for Arboriculture (N.A.K.-B.), as well as other persons, look out for good trees. Finally we ourselves travel about the country to judge the mother-trees which have already been selected or are under investigation. During these travels we often come across new well-bearing trees, which are then included in our investigations.

The standards, on which seedling selection is based are the result of economic 


\section{RESEARCH OFFERED NEW POSSIBILITIES FOR NUT GROWING}

research into the possibilities of culture. The trees have to be sufficiently fruitful (on an average at least 20 fruits per square $m$ crown-section), and healthy; flowering should occur as late as possible. The dry fruit-weight has to be at least 9 grammes apiece; fruits should not be too narrow (oblong), and must be well-filled (at least $40 \%$ of kernel), well-closed, easy to open, attractive in appearance (colour and surface), and have a fine, preferably gold-coloured kernel which can be easily taken out of the shell.

The seedlings which come up to these requirements are observed for a number of consecutive years (and judged for their fruits). If they remain good, they are submitted to a Nut Committee for approval. This Committee is composed of representatives of the Inspection Service and of the Advisory Service, of producers, growers and consumers. The origin of approved varieties is passed on to the Inspection Service which sees to it that scions are supplied to the nurserymen. In addition, a list of approved varieties is published yearly in the agricultural periodicals and the Netherlands List of Fruit Varieties.

The mother-trees of approved varieties are kept under observation for some years. In addition, some daughter-trees are planted in our experiment garden, and at a number of trial fields all over the country.

Only very few Dutch seedlings have so far been approved; many promising varieties have in the long run given results that were unsatisfactory in one or more respects. Two of the approved selections already bear a name, viz. Bell and Van Toor; the third is so far still indicated by a number only (5110). No 5110 is a good pollinator

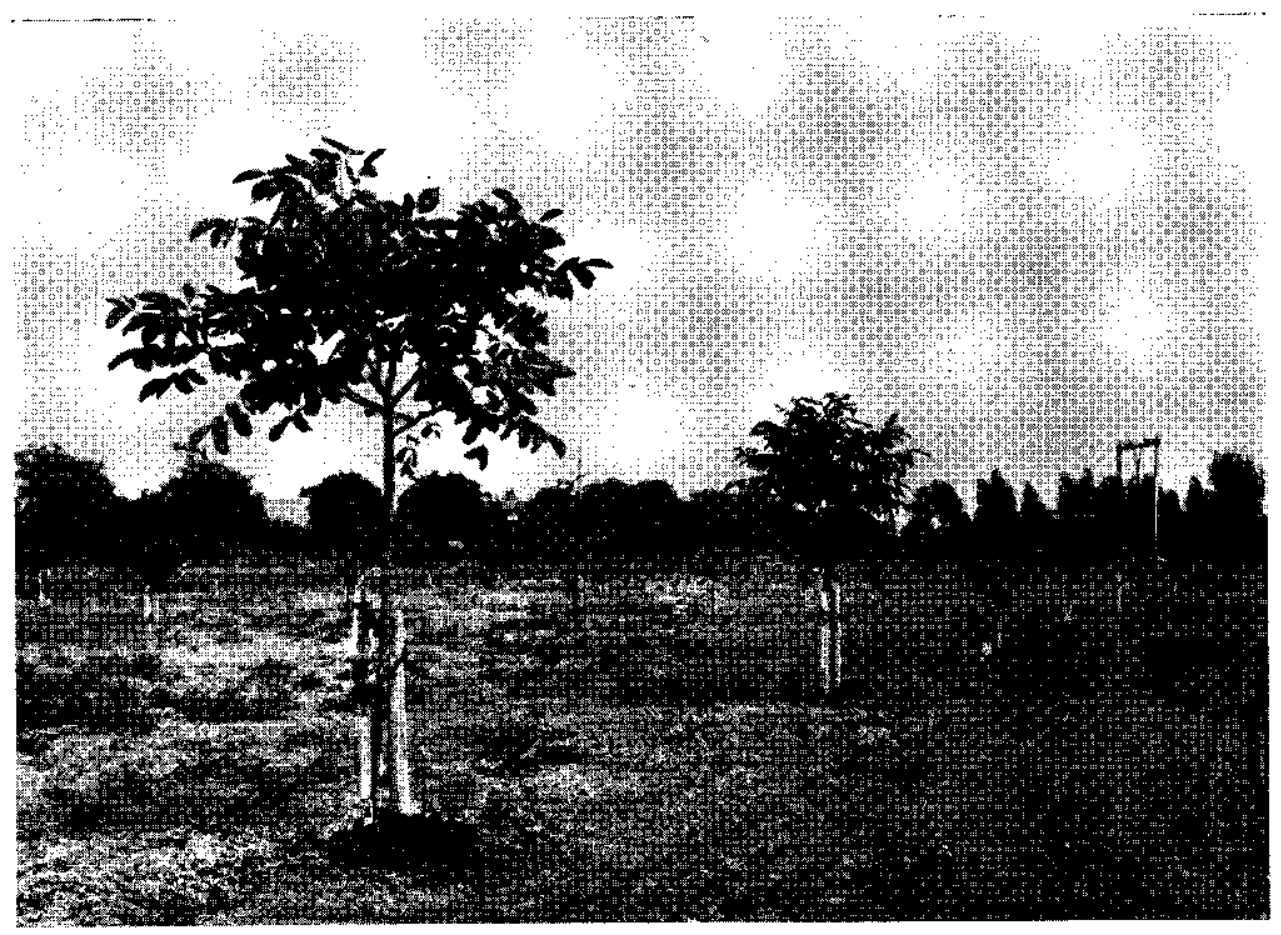

Fig. 4, SURVEY OF PART OF THE NUT SELECTION FIELD AT ELST 


\section{J. GERRITSEN}

for the majority of the Dutch, German and French varieties, and can also be pollinated itself by these varieties.

German and French varieties cannot yet be approved, as there have been no trees to be judged; thus fruitfulness could not be determined. Yet these varieties, too, are being propagated and recommended for trial, on account of 1 . the good reputation of the French varieties and of the German selectors, 2. the lack of scionwood (at least at first) of the Dutch selections, and 3. the risks involved in planting Dutch selections only. The question of suitable varieties will have to be finally settled by the experimenters and the practical growers.

\section{CONCLUSION}

When it appeared that nuts could be grown profitably in the Netherlands, publications on this matter were inserted in the journals, also with the hope of discovering sources of good seedlings. A flood of letters asking for information was the result. Letters are still coming in regularly, mostly from people who want to plant. The more official bodies also show an increasing interest in this crop. Thus the data on the nut has also been included in the List of Varieties during the last few years.

Nuts are now planted more widely; instead of the few trees which used to be planted here and there, larger areas, covering several hectares, are being planted yearly. Practically all the nuts which are now being planted are grafted trees, instead of the seedlings which used to be planted.

\section{SUMMARY}

The reasons of the decrease in the number of walnuts grown in the Netherlands are discussed.

The increased interest during and shortly after the war disappeared soon afterwards, because of the fact that one could not plant grafted trees. It mostly takes very long before seedlings come into bearing, and in addition many seedlings bear fruits of poor quality, and small size.

Economical and technical research showed that it will be possible to grow walnuts commercially in the Netherlands. Therefore a practical propagation-method was developed by Mr. FLOOR, and good seedlings were selected for propagation in combination with a number of good foreign varieties.

The demands to be made upon varieties and seedlings to be approved are discussed, as well as the way in which the search for these seedlings is organised.

The approved varieties are described in the List of Fruit Varieties; the mother trees, and afterwards the daughter trees which are planted in trials, are inspected for a number of consecutive years in order to know which are the best varieties. The fruits too are inspected.

The best Dutch varieties are Bel and van Toor; a pollinator for these varieties and the foreign ones is 5110 .

Since grafted nut trees can be bought from some nurseries, the planting of nuts for commercial purpose is increasing. 


\section{SAMENVATting}

Research opende nieuwe perspectieven voor de notenteelt in Nederland

In het begin van deze eeuw bedroeg het aantal notebomen in ons land enige honderdduizenden. Dit waren zaailingen. Door economische, militaire en psychologische oorzaken werden een groot aantal bomen gerooid, terwijl dit ook geschiedde als gevolg van de voorschriften dat notenbomen niet meer langs rivierdijken mogen staan. Bovendien werden er weinig noten geplant.

Dank zij het rassenonderzoek en het ontwikkelen van een voor noten geschikte entmethode is het thans mogelijk aanbevelenswaardige rassen te vermenigvuldigen en daardoor de notenteelt op hoger niveau te brengen. Als gevolg hiervan neemt de belangstelling voor de notenteelt toe.

De Rassenlijst voor Fruit geeft een overzicht van de aanbevelenswaardige rassen terwijl de voorziening van enthout geschiedt onder toezicht van de N.A.K.-B. 


\section{MEDEDELINGEN ${ }^{1}$ ) \\ VAN HET INSTITUUT VOOR DE VEREDELING VAN TUINBOUWGEWASSEN}

36. Hofstra, R. en M. Keuls. Onderzoek naar de opbrengst van nicotine en Nicotiana rustica (L.) over de jaren 1949-1950. Juli 1952

37. Banga, O. en M. Keuls. Practijkproeven wortelen Amsterdamse Bak 1949-1950. Juli 1952 . . . Uitverkocht

8. Banga, $\mathbf{O}$, en $M$, Keuls. Practijkproeven zomerwortelen 1949-1950. Juli 1952 . . . . . . Uitverkoche Kronenberg, H.G, Verejelingswerk met de aardbei op het I.V.T. October 1952 . . . . . . . Vitverkocht

40. Floor, J. Proeven met vermeerdering door entstekken. October 1952

October 1952 . Banga, $O$. Some factors in the growth rate of red garden beets. Novernber 1952

42. Sneep, J. Practijkproeven met Westlandse Boerenkool 1949-1950 en 1950-1951. December 1952 f 1,-

43. Een bos enthoutjes. Januari 1953

44. Banga, O. Practijkproeven met Ronde Rode Radijs 1951-1952. Februari 1953 . . . . . .

5. Gerritsen, C. J. De rassenkeuze bij de Walnoot. Maart 1953. H. G. De veredeling van KleinFruit in de Ver. Staten van Amerika .....f 0,65

47. Banga, O. en M. Keuls. Practijkproeven met Berlikumer Wortel 1949. April 1953.

48. Gerritsen, C. J. Welke kersen moeten we planten. April 1953 . We ten, April 1953 . '位 en M. Wattel. Practijkproeven met. Flakkeese Winterwortel 1950-1951. Mei 1953 .

Algemene Veredelingsdagen 1952. Verslag van voordrachten en discussies. Juni 1953 . . * .

51. Sneep, J. Practijkproeven met Spitskool 19491950 en 1950-1951. Juli $1953 \ldots . . . . .$.

52. Boom, B. K. Internationaal reglement voor de Kaamgeving van gekweekte planten . - . . - OpKronenberg, H. G. en F. Garretsen. Op 1953 .

54. Veredelingsdag Groentegewassen 1953. Verslag van voordrachten en discussies. December 1953 . . f 1,-

55. Floor, J. Planten in plastic. Januari 1954 . . Uitverkocht 56. Banga, $O$. Taproot-problems in the breeding of root vegetables. A Kraai, Practijkproeven met 0,25 Kool 1950-1951. Juni 1954 .

8. Jensma, J. R. en A. Kraai. Practijkproeven met Spruitkool 1950-1951. Juli 1954. . . . . . . f 0,85 59. Veredelingsdag Fruitgewassen $1954^{\circ}$. Verslag van voordrachten en discussies. Augustus 1954 .... f 0.95

60. Kraai, A. The use of Honey-bees and Bumble-bees in breeding work. September $1954 \ldots \ldots$. . . f 0.45

61. Jensma, J. R. en A. Kraai. Practijkproeven met Witte Kool 1952-1953. Februari 1955 . . . . . . . . . f 1,35

62. Banga, O. en J. W. de Bruyn. Selection of Carrots for Carotene Content. februari 1955 ...... f 0,25
63. Kronenberg, H. G. en L. M. Wassenaar. Practijkproeven met aardbeirassen 1952-1954. April 1955 - f0.90 64. Keuls, M. and J. W. Sieben. Two statistical problems in plant selection. April $1955 \ldots$....... f 0.35

65. Banga, $O$. The Institute of Horticultural Plant Breeding. April 1955 . . . . . . . f 0,25 66. Banga, 0 . Uienveredeling met getruikmaking van inteelt en herstel door heterosis. Juni 1955 ... . . . f 0.30

67. Banga, O. Carrot yield analysis. September 1955 . f 0,30

68. Banga, O., J. W. de Bruyn and L. Smeets. Selection of carrots for carotene content. II Sub-normal content at low temperature. September 1955 . f 0.25

69. Braak, J. P. Effect of temperature and light on June Yellows in strawberries. September 1955 .... f 0,25

70. Banga, $O$. De ontwikkeling van de rassensituatie bij groentegewassen. Oktober 1955 . . . . . f 0,25

71. Bruyne, A. S. de. Tendenzen in de ontwikkeling van het Nederlandse fruitsortiment. Oktober 1955 ... f 0,40

72. Banga, O. Praktijkproeven met Knolselderij 1953-1954. November 1955. . . . . . . . . f 0,30

73. Floor, J., Proeven met stekken onder waterverneveling. April 1956 . . . . . . f $1,-$

74. Andeweg, j. M. en j. H, Ruyten. Praktijkproeven met Tomaten 1954-1955. April 1956 ........ f 0.40

75. Andeweg, J. M. en A. van Steenbergen. Praktijkproeven met Stoksnijbonen 1953-1954. Mej 1956 ... 0,35

76. Banga, $O$. en J. L. van Bennekom. Praktijkproeven met Ronde Witpunt Radijs 1953-1954. Mei 1956. . f 0,55

77. Smeets, L, and Hester G, Kronenberg. Runner formation on strawberry plants in autumn and winter. Smeets, L. Runner formation on strawberry plants in autumn and winter. If. Influence of the light intensity on the photoperiodical behaviour. Juni 1956... f 0,30

78. Smeets, L. Influence of che temperature on runner production in five strawberry varieties. Juni 1956 . . f 0,25

79. Smeets, L. and L. M. Wassenaar. Problems of heat spot in Fragaria resca $L$. when indexing strawberry selections for viruses. Juni $1956 \ldots \ldots$. . . . . . 0,50

80. Banga, $O$. and J. W. de Bruyn. Selection of carrots for carotene content. IJl Planting distances and ripening equilibrium of the roots. Juni 1956 ....... f 0,35

81. Banga, $O$. International conference on the improvernent and on the stanjardization of vegetable varieties at Wageningen, Netherlands, on August 26 and 27, 1955. August 1956 ............ f 0.75

82. Floor, J. Proeven met vermeerdering van houtiga g $\cong-$ wassen. Seprember $1956 \ldots$..... 0,80

83. Gerritsen, C. J. Improvement of the cherry varieties used in the Netherlan Js. Oktober 1956 ..... f 0.35

84. Gerritsen, C. J. Research offered new possibilities for nut growing in the Netherlands. Okcober 1956 . . . 0,25

\section{PERSBERICHTEN UITSLAGEN PRACTIJKPROEVEN}

10- 3-50. Uitslag Practijkproeven Wortel Berlikumer 1949

29-11-'50. Uitslag Practijkproeven Bak-en Zomerwortelen 1949-1950.

29-11-'50. Uitslag Practijkproeven Platronde en Ronde Kroten 1949-1950.

22-12-'50. Uitslag Practijkproeven Pronkbonen 1950.

11- 3-'51. Uitslag Practijkproeven Westlandse Boerenkool 1949-1950.

3- 9-'51. Uitslag Practijkproeven Spitskool 1950-1951.

7-12-'51. Uitslag Practijkproeven Flakkeese Winterwortel 1950-1951.

23- 1-52. Uitslag Practijkproeven Vroege en Herfst Rodekool 1950-1951.

31- 3-'52. Uitslag Practijkproeven Spruitkool 1950-1951.

4-11-'52. Uitslag Practijkproeven Ronde Rode Radijs 1951-1952.

4-11-'52. Uisslag Practijkproeven Vroege Rijspeulen 1951-1952.

25-11-'52. Uitslag Practijkproeven Lange Kroten 1951-1952.

23- 1-'53. Uitslag Practijkproeven Radijs Ronr'e Seharlakent ode Extra Kortloof 1951-1952.

13- 5-'53. Uitslag Practijkproeven Bewaar Rode Kool 1951-1952.

10- 9-'53. Uitslag Practijkproeven Vroege Witte Kool 1952-1953.

18-12-'53. Uitslag Practijkproeven Herist Witte Kool 1952-1953.

3- 6-'54. Uitslag Practijkproeven Bewaar Witte Kool 1952-1953.

17-11-'54. Uitslag Practijkproeven Stoksnijbonen 1953-1954

2-P2-'54. Uitslag Practijkproeven Ronde Rode Witpunt Radijs 1953-1954.

12- 2-'55. Uitslag Practijkproeven Knolselderij 1953-1954.

1- 9-'55. Uitslag Practijkproeven Vroege Groene Savoye Kool 1954-1955.

14-11-'55. Uitslag Practijkproeven Tomaten 1954-1955.

27 12-'55. Uitslas Practijkproeven Witlof vroege crek 1954-1955.

2-3-'56. Uitslag Practijkproeven Witlof middelvroege trek 1954-1955.

5-3-'56. Uitslag Practijkproeven Schorseneren 1954-1955

28- 5-'56. Uitslag Practijkproeven Savoye Kool 1954-1955.

28- 5-'56. Uitslag Practijkproeven Witlof koude kuil en meilof 1954-1955.

30- 7.'56. Uitslag Practijkproeven Tuinbonen 1955-1956.

1- 9.'56. Uitslag Praktijkproeven Amsterdamse Bakwortel 1955-1956

1- 9-'56. Uitslag Praktijkproeven Vroege Rode Kool 1956

1- 9.'56. Uitslag Praktijkproeven Platronde Kroten 1955-1956

Zijn geplaatst in diverse tuinbouwbladen. 


\section{RASSENLIJSTEN ${ }^{1}$ ) \\ UITGEGEVEN DOOR HET INSTITUUT VOOR DE VEREDELING VAN TUINBOUWGEWASSEN}

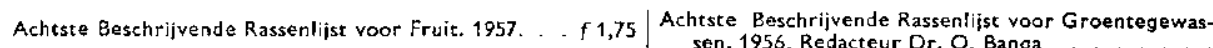
$f \mathbf{1 , 7 5}$

\section{JAARVERSLAGEN ${ }^{1}$ )}

VAN HET INSTITUUT VOOR DE VEREDELING VAN TUINBOUWGEWASSEN

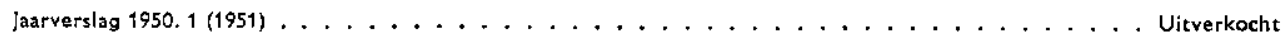

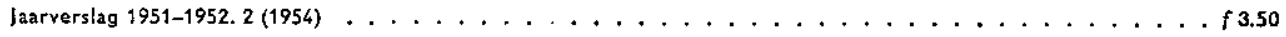

\section{PUBLIKATIES VAN HET INSTITUUT VOOR DE VEREDELING VAN TUINBOUWGEWASSEN IN ANDERE ORGANEN OF IN BOEKVORM EVENTUEEL IN SAMENWERKING MET ANDERE INSTELLINGEN ${ }^{2}$ )}

De publikaties, waarvan prijs èn uitgever worden vermeld zijn verkrijgbaar in de boekhandel. Overigens wende men zich tot de opgegeven bronnen of toc de bibliotheek van hec I.V.T.

Elzenga, G. De selectie van Angelica-wortel op wortelgewicht| Broertjes, C. Veredeling op ziekteresistentie bij rozen. De en vluchtige oliegehalte in verband met milieu-factoren. V.N.K.-Nieuws 1955: 34-39, 42-47.

Gerritsen, C. J. De selectie van (okker)-noten. Dendrologisch laarboek 1954: 40-43.

Jensma, J. R. Mei in Mecheler. Groenten en Fruit 10, 1955: 1292.

Floor, J. en P. A. Wezelenburg. Planten in plastic. Uitg. I.V.T. Juni 1955, 10 p. f 0,25.

Banga, 0 . De plantenveredeling als factor in de strijd om het bestaan. Extra nummer Landbouwkundig Tijdschrift Mei 1955 en Zaadbelangen 9. 1955: 173-174, $187-188$.

Kronenberg, H. G. Ervaringen met aardbeirassen in 1955. Groenten en Fruit 11, 1955 : 138.

Elzenga, G. Het kweken van plantmateriaal van Valeriaan. V.N.K.-Nieuws 1955: 70-72.

Jensma, J.R. Is spics + vroeg + groen = Vroege Groene Spitse? Groencen en Fruit 11, 1955: 221.

Elzenga, G. Digitalis lanata. V.N.K.-Nieuws 1955: 87-91.

Boom, B. K. Notes on culcivated plants. Acta Botanica Neerlandica 4, 1955: 167-171.

Banga, $O$. Het XIVe Internationale Tuinbouwcongres. Zaadbelangen 9, 1955 : 232-233.

Gaag, H.C. v. d. Het kweken en het gebruik van vleesvliegen bij het veredelingswerk. Zaadbelangen 9, 1955: 233-236.

Elzenga, G. Veredelingsproblemen bij Angelica archangelica. Meded. Dir. Tuinbouw 18, 1955: 748-752.

Floor, $J$. Problemen bij de selectie van rozenonderstammen. Meded. Dir. Tuinbouw 18, 1955: 706-710.

Kronenberg, H.G. (I.V.T.) en J.J. Doesburg (I.B.V.T.). Meer aandachs voor het vitamine-C-gehalte van zwarte bessenrassen. Groenten en Fruic 11, 1955: 365. De Fruitteelt 45, 1955: 869 .

Banga, $O$. De benaming van rassen. Zaadbelangen 9, 1955: 247-248.

Boom, B. K. Cotoneaster wardii en verwante soorten. De Boomkwekerij 11, 1955: 3.

Gerritsen, C. J. Zit er wat in de teelt van hazelnoten? De Fruitteelt 45, 1955: 865 .

Kronenberg, H. G. Aardbeien. Wat moeten we toch planten? De Fruitteelt 45, 1955: 866-867.

Gerritsen, C. J. Gaat U kersen planten? De Fruitteelt 45, 1955: 909-910.

Burg, J. P. L. L. A. en G. Elzenga. Rapport over een studiereis aangaande de teelt en verwerking van geneeskrachtige en aromatische gewassen in Duitsland en Frankrijk $(16 \mathrm{t} / \mathrm{m}$ 31 augustus 1955). V.N.K.-Nieuws, september 1955: 92-99.

Boom, B. K. Sorbus pratti en S. koeneana. De Boomkwekerjj 11, 1955: 27.

Elzenga $G$. Het rooien van de wortels van Angelica en $V$ aleriaan. V.N.K.-Nieuws, november 1955: 110-111

Elzenga, G. Pepermunc opnieuw inplanten. V.N.K.-Nieuws, november 1955: 112.

Boom, B. K. Vraagstukken rondom het Cotoneaster-sortimen. De Boomkwekerij 11, 1955, 41-42.

Jensma, J. R. Rassenkeuze bij bloemkool. Groenten en Fruit 11, 1956: 721

Bruyne, A. S. de. Nieuwe appelrassen tot James Grieve. De Fruitwereld 1, 1956; no 4; 8-9.

Boom, B. K. Cercidiphyllum. De Boomkwekerij 11, 1955: 27.

Broertjes, $C$. Reactie op vragstukken rondom het Cotoneastersortiment. De Boomkwekerij 11, 1956; 67-68. Boomkwekerii 11, 1956: 73.

Boom, B. K. Acer platanoides, reitenbach' en ,rubrum" De Boomkwekerij 11, 1956: 74.

Bruyn, J.W. de. De exportcontrole van kruiden in 1955. V.N.K.-Nieuws, januari 1956: 134-135.

Boom, B, K, Buxus, buksus of buks. De Boomkwekerij 11, 1956: 80-81.

Boom, B. K. Drie nieuwe wilgen. De Boomkwekerij 11, 1956: $81-82$.

Boom, B. K. Enkele bontbladige bomen. De Boomkwekerij 11, $1956: 88$.

Boom, B. K. Een nieuwe monographie over het geslacht Philadelphus. De Boomkwekerij 11, 1956: 96-97.

Gerritsen, C. J. Zal de noot een deugd worden? De Fruitwereld 1, 1956; no. 14: 5.

Banga, O. Énkele opmerkingen naar aanfeiding van een internationale conferencie. Zaadbelangen 10, 1956: 101-102.

Kronenberg, H. G. Strawberry growing in the Netherlands. American Fruit Grower 76, 1956: no. 4: 77.

Elzenga, G. Lobelia inflata. V.N.K.-Nieuws, maart 1956: 163166.

Boom, B. K. Variëteit en cultivar. De Boomkwekerij 11, 1956: 112-113.

Andeweg, J. M. Vroegrijpende moneymaker's. Zaadbelangen 10, 1956: 145 .

Boom, B. K. Verwarring over de plantennamen. Vakblad voor de Bloemisterij 11, 1956: 130-131.

Gijsbers, J. W. Ruimtebesparing bij de opberging van dia's en negarieven. Meded. Dir. Tuinbouw 19, 1956: 298-300 Boom, B. K. Over een verzameling prijscouranten. De Boomkwekerij 11, 1956: 128-129.

Boom, B. K. Een Amerikaan over Boskoop. De Boomkwekerij 11, 1956: 130.

Huyskes, J. A. Klauwenselectie bij asperges geeft goede resultacen. Boer en Tuinder (Land en Vee) 10, 1956; no. $482: 17$.

Koot, Y. v. en J. M. Andeweg. De groenteteelt in Amerika. 's-Gravenhage, C.O.P., 1956. 149 blz. $f$ 7,00.

Banga, $\mathbf{O}$. Kweker en overheid in de sector groentezaden. Zaadbelangen 10, 1956: 189-190.

Kho, Y. O. Opbrengstvermindering en kiemkrachtverlaging van wortelzaad als gevolg van aantasting door wantsen. Zaadbelangen 10, 1956: 193-194.

Elzenga, G. Digitalis lanata Ehr. V.N.K.-Nieuws 1956: 167-170, 193-199.

Andeweg, J. M. Rationalisatie en rassenkeuze. Groenten en Fruit 12, 1956: 111

Kho, Y, O. en J. P. Braak. Opbrengstvermindering en kiemkrachtverlaging van wortelzaad als gevolg van aantasting door wantsen. Meded. Dir. Tuinb. 19, 1956: 440-445.

Kronenberg, H. G. Prakcijkproeven met aardbeien in 1956 De Tuinderij 36, 1956, no 33: 1-3. Groenten en Fruit 12, $1956: 177$.

Floor, J. en P. A. Wezelenburg. Stekken onder plastic. De Boomkwekerij, 11, 1956: 174-175.

Terpstra, $W$. Some factors influencing the abscission of debladed leaf petioles. Acta Botanĩca Neerlandica 5, 1956: 157.170

Bruyne, A. S. de. Trends and developments in Dutch varieties. The Commercial Grower 1956, no 3165: 419-422.

1) Zolang de voorraad strekt kunnen deze publikaties franco worden toegezonden, na ontvangst van het vermelde bedrag op giro no. 425340 van het Instituut voor de Veredelang van Tuinbouwgewassen, S. L. Mansholtlaan 15 te Wageningen onder vermelding van wat verlangd wordt; ook bestaat de mogelijkheid deze publikaties uit de bibliocheek van het I.V.T. te lenen.

verder versehenen publikazies zijn vermeld achterin in de Mededelingen nos $1 \mathrm{t} / \mathrm{m} 70$. 